\title{
Tumour-derived exosomes and their role in cancer-associated T-cell signalling defects
}

\author{
DD Taylor ${ }^{*, 1,2}$ and C Gerçel-Taylor ${ }^{1,2}$ \\ 'Department of Obstetrics, Gynecology \& Women's Health, University of Louisville School of Medicine, Louisville, KY 40202, USA; '2Department of \\ Radiation Oncology, University of Louisville School of Medicine, Louisville, KY 40202, USA
}

\begin{abstract}
Dendritic and lymphoid 'exosomes' regulate immune activation. Tumours release membranous material mimicking these 'exosomes,' resulting in deletion of reactive lymphocytes. Tumour-derived 'exosomes' have recently been explored as vaccines, without analysis of their immunologic consequences. This investigation examines the composition of tumour-derived 'exosomes' and their effects on T lymphocytes. Membranous materials were isolated from ascites of ovarian cancer patients $(n=6)$ and Western immunoblotting was performed for markers associated with 'exosomes.' Using cultured T cells, 'exosomes' were evaluated for suppression of CD3- $\zeta$ and JAK 3 expressions and induction of apoptosis, measured by DNA fragmentation. 'Exosome' components mediating suppression of CD3- $\zeta$ were isolated by continuous eluting electrophoresis and examined by Western immunoblotting. 'Exosomes' were shown to be identical with previously characterised shed membrane vesicles by protein staining and TSGIOI expression. 'Exosomes' expressed class I MHC, placental alkaline phosphatase, B23/nucleophosmin, and FasL. 'Exosomes' suppressed expression of T-cell activation signalling components, CD3- $\zeta$ and JAK 3 and induced apoptosis. CD3- $\zeta$ suppression was mediated by two components: 26 and $42 \mathrm{kDa}$. Only the $42 \mathrm{kDa}$ component reacted with anti-FasL antibody. These results indicate that, while 'exosomes' express tumour antigens, leading to their proposed utility as tumour vaccines, they also can suppress T-cell signalling molecules and induce apoptosis.
\end{abstract}

British Journal of Cancer (2005) 92, 305-31।. doi:I0.1038/sj.bjc.66023 I6 www.bjcancer.com

Published online 18 January 2005

(c) 2005 Cancer Research UK

Keywords: exosomes; activation signaling; membrane vesicles; $T$ lymphocytes; ovarian cancer

One general characteristic of tumours is their ability to release or shed intact, vesicular portions of membrane material (termed membrane fragments, membrane vesicles, microvesicles or exosomes), which was initially described by us, 25 years ago (Taylor and Doellgast, 1979; Taylor et al, 1980). Recently, these tumourderived vesicles, or 'exosomes,' have gained attention as a source of tumour antigens for vaccines, either directly or as part of processed dendritic cells or dendritic cell-derived vesicles (André et al, 2002a, b; Chaput et al, 2003; Kim et al, 2004).

Membrane vesicle shedding and its accumulation appear to be important features of the malignant transformation. Shed tumourderived membrane vesicles do not mirror the general composition of the plasma membrane of the originating tumour cell, but represent 'micromaps,' with enhanced expression of tumour antigens (Taylor and Black, 1986, 1987; Taylor et al, 1988). While the precise mechanism of shedding remains unclear, the release of membrane vesicles has been demonstrated to be an energyrequiring phenomenon of viable cells, modulated by extracellular signals (Taylor et al, 1983a, 1988). The rate of shedding is

\footnotetext{
*Correspondence: Dr DD Taylor, Division of Gynecologic Oncology, University of Louisville School of Medicine, 5 I I South Floyd Street, MDR 420, Louisville, KY 40202, USA; E-mail: ddtaylor@louisville.edu

Received 31 August 2004; revised 26 October 2004; accepted 8 November 2004; published online 18 January 2005
}

significantly increased in most neoplastic cells and occurs continuously (Taylor and Black, 1986, 1987; Taylor et al, 1983a, $1988,2002)$. In addition to cancer cells, the release of membrane vesicles was also demonstrated to be associated with cells of embryonic origin (such as the placenta) and activated lymphoid cells (Taylor and Black, 1986, 1987; Heijnen et al, 1999; Denzer et al, 2000). Although extracellular shedding of membrane-derived vesicles occurs in other types of cells, under specific physiological conditions, the accumulation of shed membrane vesicles from non-neoplastic cells is rarely observed (Taylor and Black, 1986; Taylor et al, 2002).

Since shed membrane vesicles exhibit molecules with biologic activity (such as Fas ligand, mdr 1, CD44, and autoreactive tumour antigens) (Taylor et al, 1983b, 1984, 1989, 1996, 2002), the ability of these shed membrane vesicles to modulate lymphocyte and monocyte functions have been analysed in several tumour models. Membrane vesicles released by metastatic tumour cells suppressed the expression of class II MHC antigens by monocyte/macrophages in a dose-dependent manner, while similar vesicles from early stage tumour cells did not (Taylor and Black, 1985; Poutsiaka et al, $1985 \mathrm{a}, \mathrm{b})$. The shed membrane vesicles were also shown to suppress lymphocyte activation with phytohaemoglutinin, Concanavalin A, or antiCD3 (Taylor et al, 1988). These shed tumourderived membrane vesicles also inhibited the activation of lymphocytes with interleukin-2 (Pelton et al, 1991). Our recent findings have demonstrated that these membrane vesicles can also 
suppress the expression of $\mathrm{CD} 3-\zeta$ and subsequent activation signalling, inhibiting proliferation and cytokine production (Taylor et al, 2003).

We have theorised that these shed vesicles modulate lymphocyte functions by mimicking 'activation-induced cell death' (AICD) (Taylor and Black 1986; Martinez-Lorenzo et al, 1999). Lymphoid cells appear to release membrane vesicles following activation and these appear to play an essential role in immunoregulation, preventing of excessive immune responses and the development of autoimmunity (Green et al, 2003). It was postulated that membrane shedding by tumour cells was a re-expression of the fetal cell shedding and that both constituted pathways to circumvent immunosurveillance (Gerçel-Taylor et al, 2002).

These shed membrane vesicles were rediscovered in the mid1980s and termed 'exosomes' (Pan et al, 1985; Johnstone et al, 1987). These 'exosomes' were postulated to be functional extensions of antigen-presenting cells, stimulating immune responses (Théry et al, 2002). Théry characterized the composition and physical properties of this membranous material, demonstrating the ability of the centrifugal isolation procedure differentiated between exosomes and other vesicular structures and large protein aggregates Théry et al (1999). While characterizations of 'exosomes' have been consistent with our previously described shed tumour-derived membrane vesicles, in terms of size (60$100 \mathrm{~nm}$ in diameter) and general composition, the term, 'exosomes,' has separated its literature from the published immunologic activities of tumour-derived membrane vesicles. In the present study, we are attempting to bridge this gap, to definitively show identity between 'exosomes' and membrane vesicles and to establish that these shed 'exosomes' possess immunosuppressive activity.

\section{MATERIALS AND METHODS}

\section{Patient-derived materials}

Ascites were obtained from women diagnosed with stage IIIc papillary serous adenocarcinoma of the ovary $(n=6)$ in the Gynecologic Oncology Clinic of the Department of Obstetrics and Gynecology of the University of Louisville School of Medicine. Blood samples were also obtained from normal female volunteers $(n=8)$ from the Gynecology Clinic of the Department of Obstetrics and Gynecology of the University of Louisville School of Medicine. The University Human Studies Committee of the University of Louisville approved this study and informed consent was obtained from each patient. Blood samples were allowed to clot and then were centrifuged at $400 \mathrm{~g}$ for $10 \mathrm{~min}$ to sediment cells and clot. The serum was removed, aliquoted, and stored at $-70^{\circ} \mathrm{C}$ until analysis. For all of the samples studied, the age of the nontumour-bearing female volunteers was $57.2 \pm 4.1$ years, compared to $59.4 \pm 5.3$ years for women with ovarian cancer.

\section{Isolation of tumour-derived membrane vesicles}

Membrane vesicles were isolated from ascites by two separate procedures and then compared. The first protocol was the two-step chromatography/centrifugation procedure developed in our laboratory (Taylor and Doellgast, 1979; Taylor et al, 2002) and the second was the density gradient centrifugation procedure described for 'exosome' isolation (Raposo et al, 1996). In the first chromatography procedure, $10 \mathrm{ml}$ of ascites was applied to a BioGel A50m column $(2.5 \times 45 \mathrm{~cm})$ equilibrated with PBS. Fractions $(5 \mathrm{ml})$ were collected; the elution monitored by absorption at $280 \mathrm{~nm}$ and the void volume peak, containing material greater than 50 million Daltons, was collected. In the centrifugation procedure, ascites were successively centrifugated at $300 \mathrm{~g}$ for $10 \mathrm{~min}, 800 \mathrm{~g}$ for $30 \mathrm{~min}, 10000 \mathrm{~g}$ for $30 \mathrm{~min}$ and $100000 \mathrm{~g}$ for $1 \mathrm{~h}$. The pellet was then washed in PBS and floatation of membrane vesicles on a discontinuous sucrose gradient was performed at $4{ }^{\circ} \mathrm{C}$ as previously described (Raposo et al, 1996). Membrane vesicles from both procedures were then centrifuged at $100000 \mathrm{~g}$ for $1 \mathrm{~h}$ at $4^{\circ} \mathrm{C}$. The pelleted membrane vesicles were resuspended in PBS and the quantity of protein was determined by the Bradford microassay method (Bio-Rad Laboratories, Hercules, CA, USA), using BSA as a standard.

To compare the distributions of proteins in membrane materials isolated by these procedures, SDS-PAGE using a 8-15\% acrylamide gel (Laemmli, 1970) was performed, followed by silver staining (Bio-Rad Laboratories, Hercules, CA, USA). The stained gels were analysed by Kodak 1D Image Analysis software (Eastman Kodak, Rochester, NY, USA).

\section{Western immunoblots analyses of 'exosomes' protein expression}

Western immunoblotting was performed to analyse the presence of specific proteins, including HLA-A, PLAP, TSG101, FasL, B23/ nucleophosmin. Proteins from each 'exosomes' preparation $(35 \mu \mathrm{g})$ were applied per lane of a 4-20\% SDS-PAGE gel. The proteins were electrophoretically separated by the method of Laemmli (1970) and analysed by Western immunoblot as previously described (Brown et al, 1993), probing overnight at $4^{\circ} \mathrm{C}$ with either rabbit polyclonal anti-FasL $\left(1 \mu \mathrm{g} \mathrm{ml}^{-1}\right.$, Calbiochem, San Diego CA, USA), rabbit polyclonal anti-PLAP $\left(1 \mu \mathrm{g} \mathrm{ml}^{-1}\right.$, Abcam, Cambridge, MA, USA), mouse monoclonal anti-TSG101 ( $1 \mu \mathrm{g} \mathrm{ml}^{-1}$, Abcam, Cambridge, MA, USA), rabbit polyclonal anti-B23/nucleophosmin $\left(1 \mu \mathrm{g} \mathrm{ml}^{-1}\right.$, Santa Cruz Biotechnology, Santa Cruz, CA, USA), or goat polyclonal anti-HLA-A $\left(1 \mu \mathrm{g} \mathrm{ml}^{-1}\right.$, Santa Cruz Biotechnology, Santa Cruz, CA, USA) as the primary antibodies and peroxidase-conjugated anti-rabbit, goat, or mouse immunoglobulin as the secondary antibody. The bound immune complexes were visualised by enhanced chemiluminescence (ECL, Amersham Life Sciences, Arlington Heights, IL, USA) and quantitated by densitometry (Un-Scan-it Software, Silk Scientific Corp., Orem, UT, USA).

\section{Expression of signalling proteins, TcR/CD3- $\zeta$ and JAK3}

Jurkat E-61 cells, a human T-cell lymphoma, was obtained from the American Type Culture Collection (Manassas, VA, USA). These cells were utilised as an in vitro assay for lymphocyte modulation by ascites-derived 'exosomes.' This T-cell line was grown in RPMI 1640 medium supplemented with $0.1 \mathrm{~mm}$ nonessential amino acids, $1 \mathrm{~mm}$ sodium pyruvate, $200 \mathrm{~mm}$ L-glutamate, $100 \mu \mathrm{g} \mathrm{ml}^{-1}$ streptomycin and $100 \mathrm{IU} \mathrm{ml}^{-1}$ penicillin in a humidified $5 \% \mathrm{CO}_{2}$ chamber at $37^{\circ} \mathrm{C}$. Cell viability was evaluated by trypan blue exclusion. All cultures utilized for this study were $>95 \%$ viable.

For bioassay of $\mathrm{CD} 3-\zeta$ expression, viable Jurkat cells $\left(10^{6}\right.$ cells $\left.\mathrm{ml}^{-1}\right)$ were incubated in a medium supplemented with $400 \mu \mathrm{g} \mathrm{ml}^{-1}$ isolated 'exosomes' for $48 \mathrm{~h}$ and were compared with unexposed Jurkat cells or Jurkat cells exposed to the analogous gradient fractions from control sera. After 2 days, the cells were centrifuged, the cell pellet washed and used for protein analysis. To assess $\mathrm{CD} 3-\zeta$ protein, the cell pellet was lysed using $50 \mathrm{mM}$ HEPES, $\mathrm{pH} 7.2,150 \mathrm{~mm} \mathrm{NaCl}, 5 \mathrm{~mm}$ EDTA, $1 \mathrm{~mm}$ sodium orthovanadate, $2.5 \%$ Triton $\mathrm{X}-100,200 \mu \mathrm{g} \mathrm{ml}^{-1}$ trypsin/chymotrypsin inhibitor, $200 \mu \mathrm{g} \mathrm{ml}^{-1}$ chymostatin and $2 \mathrm{~mm}$ PMSF. The cell lysate was assayed for protein by the BioRad protein assay (Bio-Rad Laboratories, Hercules, CA, USA). The modulation of signalling proteins was analysed by Western immunoblot using a 15\% SDSPAGE gel, as described above with mouse monoclonal anti-CD3- $\zeta$ and mouse anti-JAK 3 antibodies (Santa Cruz Biotechnology, Santa Cruz, CA, USA) as the primary antibodies. As an additional loading control, blots were also probed using rabbit polyclonal anti- $\beta$-actin (Santa Cruz Biotechnology, Santa Cruz, CA, USA). 


\section{DNA fragmentation}

The induction of apoptosis was examined as DNA fragmentation in $\mathrm{T}$ lymphocytes. Cultures of Jurkat cells $\left(2 \times 10^{5}\right.$ cells $\left.\mathrm{ml}^{-1}\right)$ following no treatment, treatment with $400 \mu \mathrm{g} \mathrm{ml}^{-1}$ membrane vesicles, or treatment with analogous material from control serum were removed from the flask after $24 \mathrm{~h}$. DNA was isolated and electrophoresed as previously described (Gibb et al, 1997). After electrophoresis, DNA bands were visualised by $0.5 \mu \mathrm{g} \mathrm{ml}^{-1}$ ethidium bromide staining.

\section{Isolation of 'exosomes'-associated inhibitory components}

Using a continuously eluting electrophoresis system (Bio-Rad Laboratories, Hercules, CA, USA), the components of 'exosomes' mediating suppression of $\mathrm{CD} 3-\zeta$ were analysed. 'Exosomes' from two cancer patients $(500 \mu \mathrm{g}$ each) were applied to $12.5 \%$ acrylamide preparative column gels and each gel was run at $100 \mathrm{~V}$. Fractions $(1 \mathrm{ml})$ were eluted from the bottom of the gel, monitoring at $280 \mathrm{~nm}$. Proteins from aliquots $(200 \mu \mathrm{l})$ of each protein-containing fraction were precipitated using a 2-D clean up kit to remove SDS (Amersham Biosciences, Arlington Heights, IL, USA). The precipitated protein was resuspended in PBS by sonication and assayed for $\zeta$ suppression in Jurkat cells. The fractions exhibiting $\zeta$ suppression were concentrated and analysed by SDS-PAGE on a $12.5 \%$ gel and subsequently by Western immunoblotting with anti-FasL antibody.

\section{Statistical Analysis}

Western blot analyses of TSG101, HLA, PLAP, B23, FasL, CD3- $\zeta$, JAK3 were performed at least twice. Densitometric quantitation of bands on each gel was standardised to a control lane included on that gel and compared by the Kruskal-Wallis test. In the remainder of experimental data, all relative absorbance determinations were performed at least twice and the mean \pm standard error of the mean for each sample was calculated. Tests with $P<0.05$ were considered statistically significant. Statistical analysis was performed using InStat (GraphPad, San Diego, CA, USA).

\section{RESULTS}

\section{Comparison of membrane vesicles and exosomes from ascites of ovarian cancer patients}

Using ascites from ovarian cancer patients, membrane vesicles isolated by size exclusion chromatography were compared with 'exosomes' isolated by density gradient centrifugation. After standardising for protein content, the membrane materials were electrophoretically separated and the protein composition was compared (Figure 1). Based on general protein composition, chromatographically isolated membrane vesicles appear to be identical to centrifugally isolated 'exosomes' obtained from the same ascites. Subsequent analysis of TSG101 (previously demonstrated to be associated with exosomes) (Stoorvogel et al, 2002) on these membrane vesicles also indicated that the membrane materials isolated by both procedures produced identical results (Figure 2).

\section{Characterisation of antigens associated with membrane vesicles}

Western immunoblot analysis of centrifugally isolated 'exosomes' demonstrated the presence of class I histocompatibility antigens in the ascites-derived membrane vesicles, confirming the expression previously shown for tumour-derived 'exosomes' (Figure 3A). To define the origin of these membrane vesicles, the 'exosome'association of placental-type alkaline phosphatase (PLAP), a

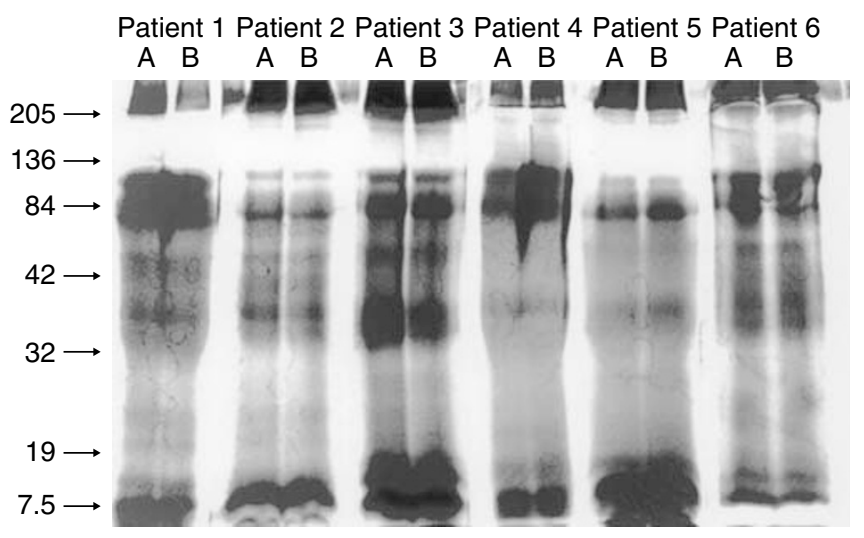

Figure I SDS-PAGE separation of chromatographically isolated membrane vesicles (designated lanes A) and centrifugally isolated 'exosomes' (designated lanes B) from the ascites of the same ovarian cancer patients, visualised by silver staining.

A
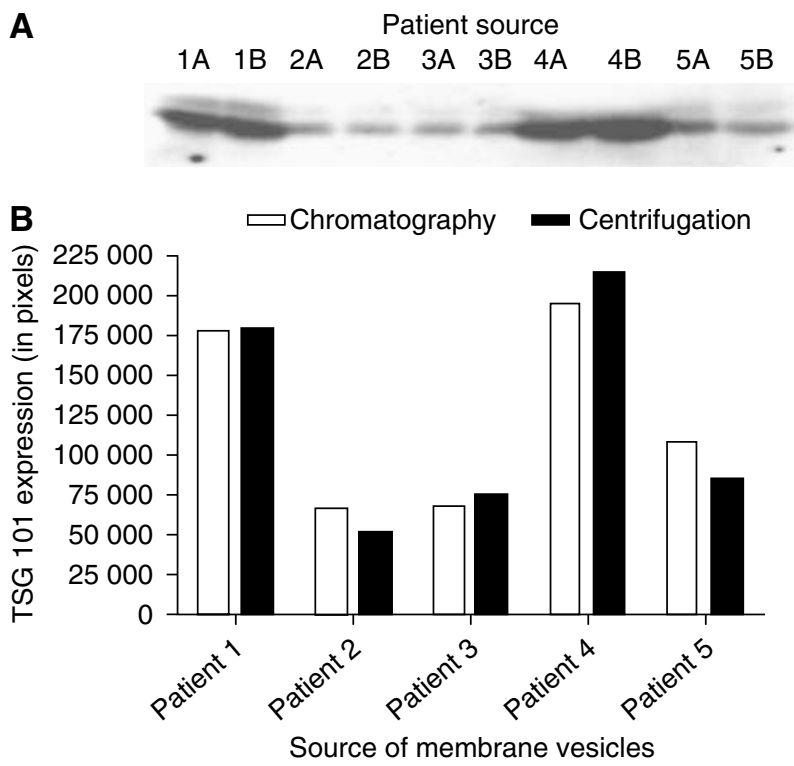

Figure 2 (A) Representative Western immunoblots of SDS-PAGE separation of chromatographically isolated membrane vesicles (designated lanes A) and centrifugally isolated 'exosomes' (designated lanes B) from the ascites of the same ovarian cancer patients, incubated with anti-TSGIOI antibody and visualised by ECL. (B) Densitometric analysis of TSGIOI expression on these membrane vesicle isolates.

plasma membrane enzyme linked with ovarian cancer, was also assayed (Figure 3D). Recent analyses at the gene and protein levels have demonstrated PLAP expression in germ cell tumours and syncytiotrophoblasts and only rarely is the protein or message observed in normal adult tissues (Shigenari et al, 1998; Goldsmith et al, 2002). All 'exosome' isolates stained positive for PLAP, indicating the probable tumour origin of these membrane materials. Our previous work demonstrated the presence of autoantibodies bound to membrane vesicles, which were reactive with B23/nucleophosmin (Katsanis et al, 1998); this finding suggested a translocation of this nuclear protein to the cell surface for exposure to the immune system. 'Exosomes' from four out of six patients were positive for the presence of B23 by Western immunoblots (Figure 3C). Since other investigators have suggested the antitumour cellular immune response can be suppressed by the presence of Fas ligand (FasL) (Rabinowich et al, 1998; Whiteside, 2002), shed 'exosomes' were assessed for expression of FasL. All 
A

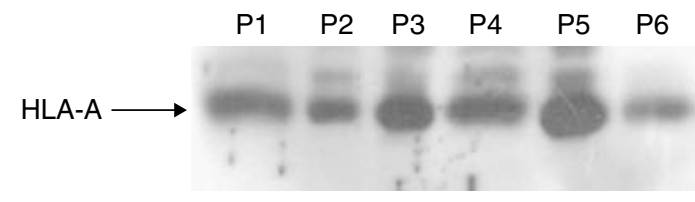

B

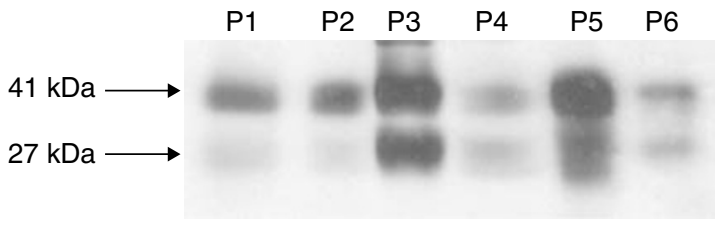

C

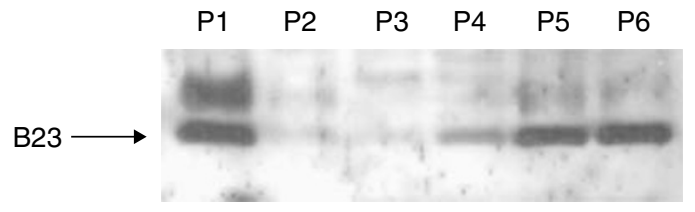

D

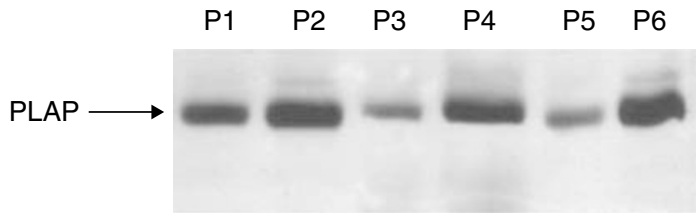

Figure 3 Western immunoblots demonstrating presence of HLA-A, Fas ligand, B23/nucleophosmin, and placental alkaline phosphatase on centrifugally isolated 'exosomes' from the ascites of ovarian cancer patients.

samples were positive for the intact $41 \mathrm{kDa}$ form of FasL and two were also strongly positive for the $27 \mathrm{kDa}$ cleaved form (Figure $3 \mathrm{~B}$ ). Although control sera failed to exhibit shed membrane vesicles, the analogous gradient fractions were analysed for the presence of HLA, FasL, B23, and PLAP and were found to be negative (data not shown).

\section{Suppression of TcR/CD3- $\zeta$ and JAK 3 protein by shed 'exosomes'}

T lymphocytes from ovarian cancer patients have been demonstrated to exhibit a loss of $\mathrm{CD} 3-\zeta$ expression and enhanced apoptosis (Rabinowich et al, 1998; Whiteside, 2002). Our work has suggested that JAK 3 may represent a common link between loss of CD $3-\zeta$ protein and induction of apoptosis. Jurkat cells were incubated for 2 days in medium containing $400 \mu \mathrm{g} \mathrm{ml}^{-1}$ of 'exosomes' or the analogous gradient fraction from control sera, and the expressions of CD3- $\zeta$ protein and JAK 3 were determined by Western immunoblot. As shown in Figure 4, CD3- $\zeta$ and JAK 3 expressions were decreased in Jurkat cells incubated with 'exosomes,' compared to those incubated with analogous control material.

\section{'Exosome'-mediated induction of apoptosis}

Since it has been hypothesised that induction of T-cell apoptosis by FasL is linked to the loss or decrease of TcR/CD3- $\zeta$ expression (Rabinowich et al, 1998), the capability of FasL-expressing 'exosomes' to induce apoptosis was examined by assessing the induction of DNA fragmentation (Figure 5). 'Exosomes' isolated from ovarian cancer patients' ascites induced significant apoptosis compared to untreated Jurkat cells or Jurkat cells incubated with the analogous control fraction.
A $\begin{array}{llllllll}C & \text { P1 } & \text { P2 } & \text { P3 } & \text { P4 } & \text { P5 } & \text { P6 }\end{array}$
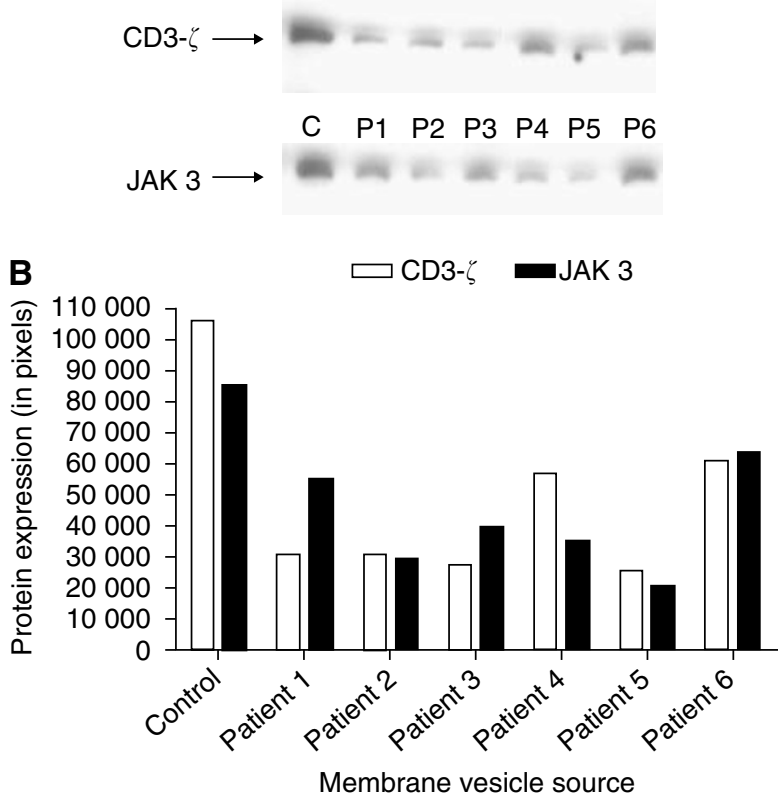

Figure 4 (A) Western immunoblots indicating the expression of CD3- $\zeta$ protein and JAK 3 by Jurkat cells, following incubation with $400 \mu \mathrm{g} \mathrm{ml}^{-1}$ of the centrifugally isolated 'exosomes' or analogous gradient material (Control, C) for $48 \mathrm{~h}$. (B) Densitometric quantitation of CD3- $\zeta$ and JAK 3 expression by treated Jurkat cells.

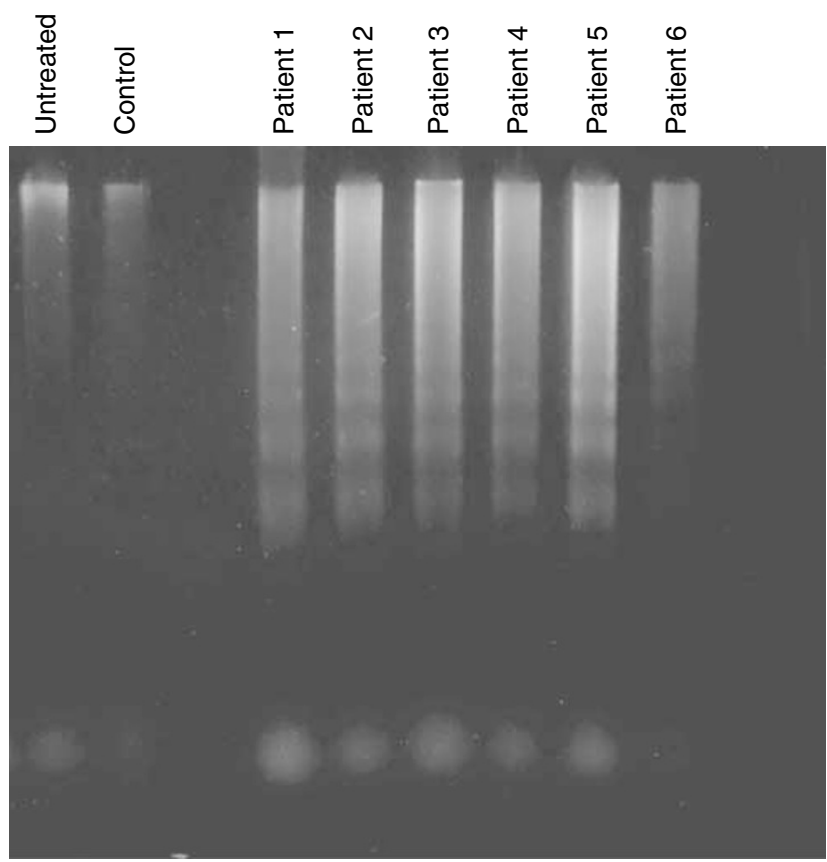

Figure 5 Induction of apoptosis in Jurkat T cells by $400 \mu \mathrm{g} \mathrm{ml}^{-1}$ of the centrifugally isolated 'exosomes' vs the analogous fraction from control female controls for $24 \mathrm{~h}$, as defined by DNA fragmentation.

\section{'Exosome'-associated inhibitory components}

Since the preparations of 'exosomes' were observed to suppress CD3- $\zeta$ and JAK 3 and to induce apoptosis within Jurkat cells, the characteristics of the inhibitory component were evaluated. 'Exosomes' from two patients were electrophoretically separated by continuously eluting electrophoresis. For each of the 'exosome' preparations, two separate fractions were identified. When these 
A

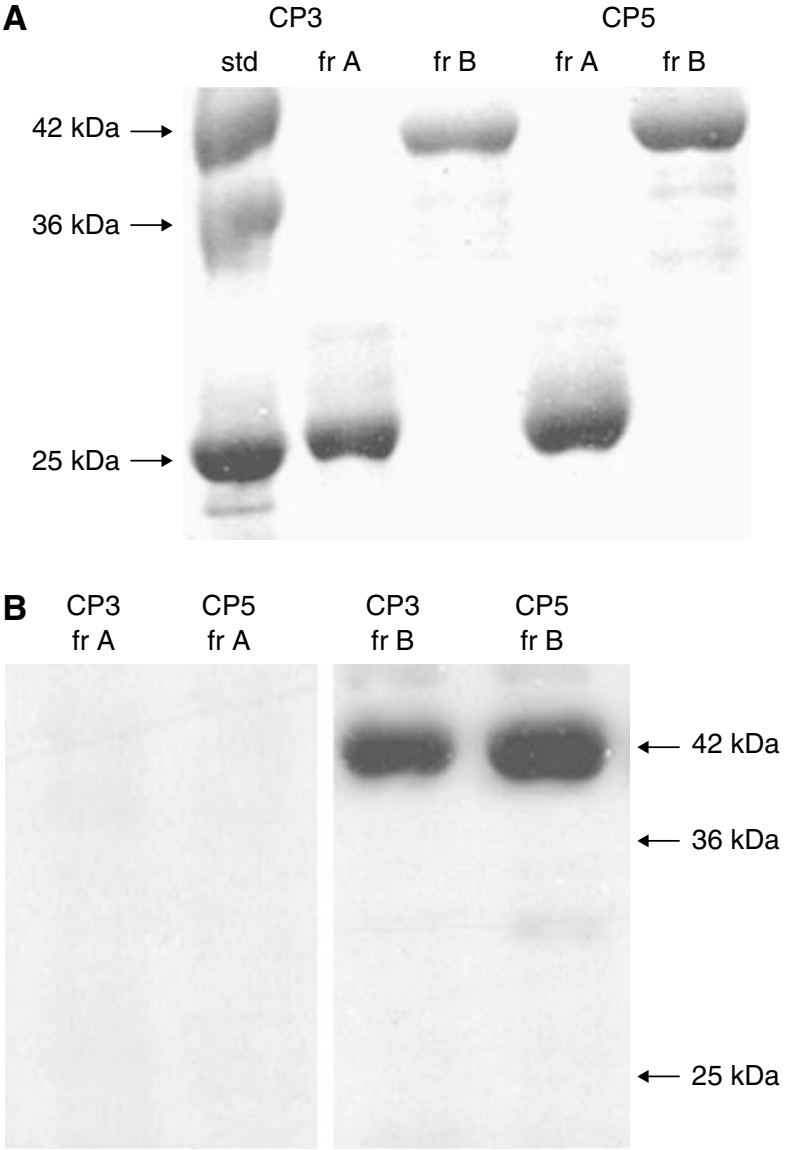

Figure 6 Identification of the 'exosomes'-associated inhibitors of $C D 3-\zeta$ expression. 'Exosomes' were fractionated by continuously eluting electrophoresis and fractions were subsequently assayed for $\zeta$ suppression in a Jurkat bioassay. The fractions suppressing $\zeta$ expression were examined by SDS-PAGE with silver staining $(\mathbf{A})$. Western immunoblotting of the two fractions with anti-FasL demonstrated reactivity with the $42 \mathrm{kDa}$ component, but not with the $26 \mathrm{kDa}(\mathbf{B})$.

components were visualised by silver staining on standard SDSPAGE gels, one component appeared at $26 \mathrm{kDa}$ and the second at $42 \mathrm{kDa}$ (Figure 6A). A separate preparation of this material was analysed by Western immunoblotting with anti-FasL antibody, since it has been implicated in suppression of CD3- $\zeta$, induction of $\mathrm{T}$-cell apoptosis and exhibits molecular weight forms at these molecular weights. Only the $41 \mathrm{kDa}$ component stained positive for FasL (Figure 6B). Since our previous studies indicated that the anti-FasL antibody used recognized both forms, the absence of reactivity with the $26 \mathrm{kDa}$ components indicates that it is not FasL.

\section{DISCUSSION}

The shedding of membrane vesicles by tumour cells and their subsequent appearance in blood specimens and malignant effusions (ascites and pleural fluids) of cancer patients has been recognised for over 25 years. These shed membrane vesicles have been implicated in the immunosuppressive events associated with advanced cancers. Owing to the presence of immunogenic tumour antigens, early evidence suggested a role in the loss of surface antigens by tumours and in competition for antibody binding (Taylor et al, 1984, 1989; Katsanis et al, 1998; Gerçel-Taylor et al, 2001). Later, data demonstrated that as tumours progressed and specific tumour subpopulations were selected or developed, these shed membrane vesicles acquired the ability to suppress cellular immunity (Taylor and Black, 1985, 1986; Pelton et al, 1991; GerçelTaylor et al, 2002; Taylor et al, 2003). The acquisition of this suppressive activity by membrane vesicles parallels the development of anergy within these cancer patients.

In the 1980s, the release of 'exosomes' by lymphoid cells was observed (Pan et al, 1985; Johnstone et al, 1987; Théry et al, 2002; Stoorvogel et al, 2002). These 'exosomes' appeared to play a central role in communication between lymphocytes and dendritic cells, mediating the development of cellular responses or suppressing excessive activation, as in AICD. The phenomena of shedding 'exosomes' have also been demonstrated with other haematopoietic cells, such as mast cells and platelets, and it is thought to play important roles mediating their actions (Raposo et al, 1997). Recent studies have isolated 'exosomes' from tumour cells in vivo and in vitro and have demonstrated the presence of tumourassociated antigens and class I MHC antigens (Wolfers et al, 2001; André et al, 2002a, b; Chaput et al, 2004). These studies have suggested that these tumour-derived 'exosomes' can serve as direct vaccines or can be processed by autologous dendritic cells, which can then be used to stimulate the anti-tumour response.

Our findings, as well as those of other investigators, have demonstrated that membrane vesicles isolated from ovarian cancer patients' peripheral blood and malignant effusions appear to be identical, in terms of general protein composition and presence of specific marker proteins (Taylor et al 1980, 2002, 2003; Graves et al, 2004). However, to date, it is unclear whether the shed tumourderived membrane vesicles are the same or distinct from tumourderived 'exosomes.' Using our published chromatographic procedure for membrane vesicle isolation and the published density gradient centrifugation protocol for 'exosomes' purification, shed membrane materials were isolated from ascites of ovarian cancer patients. Based on protein staining, there are no significant differences between the composition of these two preparations (Figure 1). Further analysis of a marker, TSG101, previously demonstrated to be associated with 'exosomes,' also demonstrated no significant differences between chromatographically and centrifugally isolated membrane materials (Figure 2).

Since 'exosomes' have been shown to exhibit HLA antigens and tumour-associated antigens, the presence of specific antigens was confirmed on ascites-derived 'exosomes.' These 'exosome' isolates expressed HLA-A antigens at similar levels (Figure 3A), as well as expressing two tumour-associated antigens (PLAP and B23) (Taylor et al, 1984; Gerçel-Taylor et al, 2001) that have previously been demonstrated to be present on membrane vesicles isolated from both peripheral blood and ascites (Taylor et al, 1980, 2002, 2003) and to generate humoral responses in autologous patients (Figure 3C and D). We further demonstrated that these shed tumour-derived 'exosomes' expressed primarily the proapoptotic, intact $41 \mathrm{kDa}$ FasL (Figure 3B).

Whiteside (2002) has proposed a link between T-cell apoptosis and decreased CD3- $\zeta$ expression. Her work previously demonstrated that coincubation of $\mathrm{T}$ lymphocytes with FasL-expressing ovarian tumour cells resulted in both loss of $\mathrm{CD} 3-\zeta$ and induction of lymphocyte apoptosis (Rabinowich et al, 1998). The expression and release of FasL also appears to play a critical role of AICD of peripheral $\mathrm{T}$ cells and the nonlymphoid FasL expression contributes to peripheral lymphocyte deletion via apoptosis (Green et $a l, 2003)$. This study addressed the consequences of 'exosome' expression of biologically active molecules, such as FasL. When ascites-derived 'exosomes' were incubated with T cells (Jurkat cells) for $48 \mathrm{~h}$, suppression of both CD3- $\zeta$ and JAK 3 proteins were observed (Figure 4). This suppression was observed using $400 \mu \mathrm{g} \mathrm{ml}^{-1}$ of membrane proteins. Our previous work demonstrated that this membrane material was present at a level of $2.06 \pm 0.73 \mathrm{mg} \mathrm{ml}^{-1}$ in advanced ovarian cancer patients. These FasL-containing 'exosomes' were further analysed for their ability to induce apoptosis (Figure 5). Induction of significant DNA 
fragmentation was observed in T cells (Jurkat cells) within $24 \mathrm{~h}$ Fractionation of 'exosomes' revealed two distinct fractions mediating suppression of $\mathrm{CD} 3-\zeta$ (Figure $6 \mathrm{~A}$ ): 26 and $42 \mathrm{kDa}$. Western immunoblotting demonstrated the $42 \mathrm{kDa}$ component to be FasL, while the $26 \mathrm{kDa}$ component did not react with anti-FasL. Current studies are focused on sequencing the $26 \mathrm{kDa}$ component.

Our analyses of tumour-derived 'exosomes' have confirmed their identity with shed membrane vesicles; however, the use of the term 'exosomes' has caused a failure to link them with their published immunologic consequences. Since shed tumour membrane vesicles or 'exosomes' do possess tumour-derived antigens that can elicit autologous immunologic responses, the potential use of these proteins as targets for vaccines is promising; however, these antigenic components need to be separated from those components mediating suppression of $\mathrm{T}$-cell signalling and inducing apoptosis. Based on their known immunosuppressive characteristics, their potential use intact as vaccines should be performed with caution.

\section{ACKNOWLEDGEMENTS}

This work was supported by Grant number CA98166 from the National Cancer Institute.

\section{REFERENCES}

André F, Schartz NE, Chaput N, Flament C, Raposo G, Amogorena S, Angevin E, Zitvogel L (2002a) Tumour-derived exosomes: a new source of tumour rejection antigens. Vaccine 20: A28-A31

André F, Schartz NEC, Movassagh M, Flament C, Pautier P, Morice P, Pomel C, Lhomme C, Escudier B, LeChevalier T, Tursz T, Amigorena S, Raposo G, Angevin E, Zitvogel L (2002b) Malignant effusions and immunogenic tumour-derived exosomes. Lancet 360: 295-305

Brown R, Clugston C, Burns P, Edlin A, Vasey P, Vojtesek B, Kaye SB (1993) Increased accumulation of $\mathrm{p} 53$ protein in cisplatin-resistant ovarian cell lines. Int J Cancer 55: 678-684

Chaput N, Schartz NE, André F, Zitvogel L (2003) Exosomes for immunotherapy of cancer. Adv Exp Med Biol 532: 215-221

Chaput N, Taieb J, Schartz NEC, Andre F, Angevin E, Zitvogel L (2004) Exosome-based immuno-therapy. Cancer Immunol Immunother 53: $234-239$

Denzer K, Kleijmeer MJ, Heijnen HFG, Stoorvogel W, Geuze HJ (2000) Exosome: from internal vesicle of the multivesicular body to intercellular signaling device. J Cell Sci 113: 3365 -3374

Gerçel-Taylor C, Bazzett LB, Taylor DD (2001) Presence of aberrant tumour-reactive immunoglobulins in the circulation of patients with gynecologic malignancies. Gynecol Oncol 81: 71-76

Gerçel-Taylor C, O'Connor SM, Lam GK, Taylor DD (2002) Shed membrane fragment modulation of CD3- $\zeta$ during pregnancy: link with induction of apoptosis. J Reprod Immunol 56: 29-44

Gibb RK, Taylor DD, Wan T, O'Connor DM, Doering DL, Gerçel-Taylor C (1997) Apoptosis as a measure of cheomsensitivity to cisplatin and taxol therapy in ovarian cancer cell lines. Gynecol Oncol 65: 13-22

Goldsmith JD, Pawel B, Goldblum JR, Pasha TL, Roberts S, Nelson P, Khurana JS, Frederic G, Zhang PJ (2002) Detection and diagnostic utilization of placental alkaline phosphatase in muscular tissue and tumours with myogenic differentiation. Am J Surg Pathol 26: 1627 - 1633

Graves LE, Ariztia EV, Navari JR, Matzel HJ, Stack MS, Fishman DA (2004) Preinvasive properties of ovarian cancer ascites-derived membrane vesicles. Cancer Res 64: $7045-7049$

Green DR, Droin N, Pinkoski M (2003) Activation-induced cell death in T cells. Immunol Rev 193: 70-81

Heijnen HFG, Schiel AE, Fijnheer R, Geuze HJ, Sixma JJ (1999) Activated platelets release two types of membrane vesicles: microvesicles by surface shedding and exosomes derived from exocytosis of multivesicular bodies and alpha granules. Blood 94: $3791-3799$

Johnstone RM, Adam M, Hammond JR, Orr L, Turbide C (1987) Vesicle formation during reticulocyte maturation. Association of plasma membrane activates with released vesicles (exosomes). J Biol Chem 262: $9412-9420$

Katsanis WA, Shields LBE, Spinnato JA, Gerçel-Taylor C, Taylor DD (1998) Immune recognition of endometrial tumour antigens induced by multiparity. Gynecol Oncol 70: 33-39

Kim JV, Latouche JB, Riviére I, Sadelain M (2004) The ABCs of artificial antigen presentation. Nat Biotechnol 22: 403-410

Laemmli UK (1970) Cleavage of structural proteins during the assembly of the head of bacterio-phage T4. Nature 227: 680-685

Martinez-Lorenzo MJ, Anel A, Gamen S, Monle NI, Lasierra P, Larrad L, Pineiro A, Alava MA, Naval J (1999) Activated human T cells release bioactive Fas ligand and APO2 ligand in microvesicles. J. Immunol 163: $1274-1281$
Pan BT, Teng K, Wu C, Adam M, Johnstone RM (1985) Electron microscopic evidence for externalization of the transferring receptor in vesicular form in sheep reticulocytes. J Cell Biol 101: $942-948$

Pelton JJ, Taylor DD, Fowler WC, Taylor CG, Carp NZ, Weese JL (1991) Lymphokine activated killer (LAK) cell suppressor factor in malignant effusions. Arch Surg 126: 476-480

Poutsiaka DD, Schroder EW, Taylor DD, Levy EM, Black PH (1985a) Shed membrane vesicles from murine melanoma cells selectively inhibit the expression of Ia antigens by macrophages. J Immunol 134 $138-144$

Poutsiaka DD, Taylor DD, Levy EM, Black PH (1985b) Inhibition of recombinant interferon-gamma induced Ia antigen expression. J Immunol 134: $145-150$

Rabinowich H, Reichert TE, Kashii Y, Gastman BR, Bell MC, Whiteside TL (1998) Lymphocyte apoptosis induced by Fas ligand-expressing ovarian carcinoma cells: implications for altered expression of $\mathrm{T}$ cell receptor in tumour associated lymphocytes. J Clin Invest 101: 2579-2588

Raposo G, Nijman HW, Stoorvogel W, Liejendekker R, Harding CV, Melief CJ, Geuze HJ (1996) B lymphocytes secrete antigen-presenting vesicles. J Exp Med 183: $1161-1172$

Raposo G, Tenza D, Mecheri S, Peronet R, Bonnerot C, Desaymard C (1997) Accumulation of major histocompatibility complex class II molecules in mast cell secretory granules and their release upon degranulation. Mol Biol Cell 8: $2631-2645$

Shigenari A, Ando A, Baba T, Yamamoto T, Katsuoka Y, Inoko H (1998) Characterization of alkaline phosphatase genes expressed in seminoma by cDNA cloning. Cancer Res 58: 5079-5082

Stoorvogel W, Kleijmeer MJ, Geuze HJ, Raposo G (2002) The biogenesis and functions of exosomes. Traffic 3: 321-330

Taylor DD, Black PH (1985) Inhibition of macrophage Ia antigen expression by shed plasma membrane vesicles from metastatic murine melanoma lines. J Natl Cancer Inst 74: 859-867

Taylor DD, Black PH (1986) Shedding of plasma membrane fragments: neoplastic and developmental importance. In Developmental Biology, Vol. 3, Steinberg MS (ed) pp 33-57. New York: Plenum Press

Taylor DD, Black PH (1987) Neoplastic and developmental importance of plasma membrane vesicles. Amer Zool 26: $411-415$

Taylor DD, Chou IN, Black PH (1983a) Isolation of plasma membrane fragments from cultured murine melanoma cells. Biochem Biophys Res Comm 113: $470-476$

Taylor DD, Doellgast GJ (1979) Quantitation of peroxidase-antibody binding to membrane fragments using column chromatography. Anal Biochem 98: $53-59$

Taylor DD, Gerçel-Taylor C, Gall SA (1996) Expression and shedding of CD44 isoforms by gynecologic cancer patients. J Soc Gynecol Invest 3: $289-294$

Taylor DD, Gerçel-Taylor C, Jiang CG, Black PH (1988) Characterization of plasma membrane shedding from murine melanoma cells. Int $J$ Cancer 41: $629-635$

Taylor DD, Gerçel-Taylor C, Lyons KS, Stanson J, Whiteside TL (2003) Suppression of TcR/CD3- $\zeta$ by shed membrane vesicles from ovarian tumours. Clin Cancer Res 9: 5113-5119

Taylor DD, Gerçel-Taylor C, Weese JL (1989) Expression and shedding of mdr-1 antigen by variants of the murine B16 melanoma. Surg Forum 40: $406-408$ 
Taylor DD, Homesley HD, Doellgast GJ (1980) Binding of specific peroxidase-labeled antibody to placental-type alkaline phosphatase on tumour-derived membrane fragments. Cancer Res 40: 4064-4069

Taylor DD, Homesley HD, Doellgast GJ (1984) Identification of components responsible for the autologous humoral responses of ovarian cancer patients. Am J Reprod Immunol 6: 179-184

Taylor DD, Homesley HD, Doellgast GJ (1983b) Membrane-associated immunoglobulins in cyst and ascites fluids of ovarian cancer patients. Am J Reprod Immunol 3: 7-11

Taylor DD, Lyons KS, Gerçel-Taylor C (2002) Shed membrane fragmentassociated markers for endometrial and ovarian cancers. Gynecol Oncol 84: $443-448$
Théry C, Regnault A, Garin J, Wolfers J, Zitvogel L, Ricciardi-Castagnoli P, Raposo G, Amigorena S (1999) Molecular characterization of dendritic cell-derived exosomes. Selective accumulation of the heat shock protein hsc73. J Cell Biol 147: 599-610

Théry C, Zitvogel L, Amigorena S (2002) Exosomes: composition, biogenesis, and function. Nat Rev Immunol 2: 569-579

Whiteside TL (2002) Tumour-induced death of immune cells: Its mechanisms and consequences. Sem Cancer Biol 12: 43-50

Wolfers J, Lozier A, Raposo G, Regnault A, Théry C, Masurier C, Flament C, Pouzieux S, Faure F, Tursz T, Angevin E, Amogorena S, Zitvogel L (2001) Tumour-derived exosomes are a source of shared tumour rejection antigens for CTL cross-priming. Nat Med 7: 297-303 